\title{
ANALISIS PELAKSANAAN SISTEM PEMBIAYAAN MUSYARAKAH PADA BANK SUMSEL BABEL CABANG PEMBANTU SYARI'AH MUARA KELINGI
}

\author{
Oleh: \\ Anita Niffilayani \\ Dosen Tetap Fakultas Ekonomi dan Bisnis Islam (IAI) Al-Azhaar \\ Lubuklinggau
}

\begin{abstract}
Abstrak
Musyarakah adalah akad kerjasama antara dua pihak untuk usaha tertentu, dimana kedua belah pihak sama-sama menyertakan modal yang masingmasing disebut dengan syirkah. Ketentuan modal tergantung kesepakatan kedua belah pihak dan bagi hasil sesuai dengan porsi modal masing-masing. Berdasarkan hasil penelitian ini, dapat disimpulkan bahwa Pelaksanaan pembiayaan musyarakah pada Bank Sumsel Babel Cabang Pembantu Syari'ah Muara Kelingi dalam hal kerja sama dan pembagian kerugian belum sepenuhnya sesuai dengan ketentuan dasar pembiayaan musyarakah, seperti yang telah ditetapkan dalam Fatwa Dewan Syari'ah Nasional Nomor 08/DSN-MUI/IV/2000 tentang pembiayaan musyarakah. Faktor pendukung pelaksanaan sistem pembiayaan musyarakah adalah Modal, yaitu dana yang digunakan untuk pembiayaan musyarakah merupakan dana yang bersumber dari dana APBD, Tingkat promosi yang baik dan Proyek, yaitu banyaknya pembangunan dan perbaikan infrastruktur transportasi khususnya di daerah musi Rawas dan Lubuk Linnggau. Sedangkan faktor penghambatnya adalah Kurangnya minat nasabah terhadap perbankan Syari'ah terutama tentang pembiayaan dengan sistem bagi hasil, dan ketidak jujuran nasabah dalam memberikan informasi tentang laporan keuangan hasil usaha yang dijalani.
\end{abstract}

Kata kunci: Analisis Pembiayaan, Musyarakah

\section{A. Pendahuluan}

Bank Syari'ah adalah bank yang menjalankan kegiatan usahanya berdasarkan prinsip Syari'ah dan menurut jenisnya terdiri atas bank umum Syari'ah dan bank pembiayaan rakyat Syari'ah. Bank Umum Syari'ah (BUS) merupakan bank Syari'ah yang dalam kegiatannya memberikan jasa dalam lalu lintas pembayaran. Sedangkan Bank Pembiayaan Rakyat Syari'ah (BPRS) adalah bank Syari'ah yang dalam kegiatannya tidak memberikan jasa dalam lalu lintas 
pembayaran. ${ }^{1}$ Prinsip Syari'ah menurut UU No. 21 Tahun 2008, adalah prinsip hukum Islam dalam kegiatan perbankan berdasarkan fatwa yang dikeluarkan oleh lembaga yang memiliki kewenangan dalam penetapan fatwa dibidang Syari'ah. Atau dengan kata lain suatu bank yang tata cara beroperasinya mengacu kepada ketentuan-ketentuan Al-Quran dan Hadits. Dari pengertian diatas dapat disimpulkan bahwa kegiatan operasional bank tersebut mengikuti ketentuanketentuan Syari'ah Islam khususnya yang berkaitan dengan tata cara bermuamalat secara Islam. ${ }^{2}$

Dalam pelaksanaan pembiayaan, bank Syari'ah harus memenuhi dua aspek diantaranya adalah: (1) Aspek Syar'i, berarti dalam setiap realisasi pembiayaan kepada para nasabah bank Syari'ah harus tetap berpedoman pada syariat islam (antara lain tidak mengandung unsur maisir, gharar, dan riba serta bidang usahanya harus halal). Dan (2) Aspek ekonomi, berarti disamping mempertimbangkan hal-hal Syari'ah bank Syari'ah tetap mempertimbangkan perolehan keuntungan baik bagi bank Syari'ah maupun bagi nasabah bank Syari'ah. ${ }^{3}$ Pembiayaan dengan prinsip bagi hasil digunakan untuk usaha kerja sama yang ditujukan untuk mendapatkan barang dan jasa sekaligus, ketika tingkat keuntungan bank ditentukan dari besarnya keuntungan usaha sesuai dengan prinsip bagi hasil. Pada produk bagi hasil keuntungan ditentukan oleh nisbah bagi hasil yang disepakati di muka. Produk perbankan yang termasuk dalam kelompok ini dan sering digunakan oleh perbankan Syari'ah adalah musyarakah dan mudharabah. Pembiayaan musyarakah dilandasi dengan adanya keinginan para pihak yang bekerja sama untuk meningkatkan nilai aset yang dimiliki secara bersama-sama. Semua bentuk usaha yang melibatkan dua pihak atau lebih dan mereka secara bersama-sama memadukan seluruh bentuk sumber daya, baik yang berwujud maupun tidak berwujud. Dalam bahasa ekonomi hal ini biasa dikenal

\footnotetext{
${ }^{1}$ Muhammad Saleh \& Ikit, Pengantar Bank Syari'ah, Cet.1, (Lubuklinggau: Pustaka AlAzhaar, 2014), h. 67-68

${ }^{2}$ Ikit, Akuntansi Penghimpunan Dana Bank Syari'ah, Cet.1, (Yogyakarta: CV BUDI UTAMA, 2015), h. 45-46

${ }^{3}$ Muhammad, Manajemen Pembiayaan Bank Syari'ah, Cet.1 (Yogyakarta: UPP STIM YKPN, 2016), h. 40
} 
sebagai joint venture. ${ }^{4}$ Pembiayaan ini mempunyai pengaruh terhadap perkembangan ekonomi, karena pembiayaan ini di peruntukkan oleh sektor riil yang dapat menggerakkan roda perekonomian.

\section{B. Pengertian Pembiayaan}

Pembiayaan atau financing, yaitu pendanaan yang diberikan oleh suatu pihak kepada pihak lain untuk mendukung investasi yang telah direncanakan, baik dilakukan sendiri maupun lembaga. Dengan kata lain, pembiayaan adalah pendanaan yang dikeluarkan untuk mendukung investasi yang telah direncanakan. $^{5}$ Pembiayaan merupakan aktivitas bank Syari'ah dalam menyalurkan dana kepada pihak lain selain bank berdasarkan prinsip Syari'ah. Penyaluran dana dalam bentuk pembiayaan didasarkan pada kepercayaan yang diberikan oleh pemilik dana kepada pengguna dana. Bank menjalankan peran sebagai perantara keuangan. Dan mengambil "posisi tengah" diantara orang-orang atau pihak yang berlebihan dana (penyimpan, penabung, deposan) dan orangorang atau pihak yang membutuhkan atau kekurangan dana (peminjam, debitur, investor) diantara kalangan pembeli dan kalangan penjual, diantara pihak pembayar dan pihak penerima. ${ }^{6}$

Menurut Undang-Undang Perbankan No. 10 Tahun 1998, pembiayaan adalah penyediaan uang atau tagihan yang dapat dipersamakan dengan itu, berdasarkan persetujuan atau kesepakatan antara bank dan pihak lain yang dibiayai untuk mengembalikan uang atau tagihan tersebut setelah jangka waktu tertentu dengan imbalan atau bagi hasil. ${ }^{7}$ Di dalam perbankan Syari'ah, pembiayaan yang diberikan kepada pihak pengguna dana berdasarkan pada prinsip Syari'ah. Aturan yang digunakan yaitu sesuai dengan hukum Islam. Pembiayaan merupakan salah satu tugas pokok bank, yaitu pemberian fasilitas penyediaan dana untuk memenuhi kebutuhan pihak-pihak yang merupakan defisit unit.

${ }^{4}$ M. Nur Rianto Al Arif, Pengantar Ekonomi Syari'ah: Teori dan Praktik, Cet.1, (Bandung: CV Pustaka Setia, 2015), h. 361

${ }^{5}$ Muhammad, Manajemen Pembiayaan Bank Syari'ah..., h. 41

${ }^{6}$ Veitzal Rivai, Islamic Banking, (Jakarta: PT Bumi Aksara, 2010), h. 681

${ }^{7}$ Ismail, Perbankan Syari'ah, Cet. 1, (Jakarta: Kencana, 2011), h. 106 


\section{Tujuan Pembiayaan}

Secara umum, tujuan pembiayaan dibedakan menjadi dua kelompok yaitu; tujuan pembiayaan untuk tingkat makro dan tujuan pembiayaan untuk tingkat mikro. ${ }^{8}$ Secara makro, pembiayaan bertujuan untuk:

a. Peningkatan ekonomi umat, artinya: masyarakat yang tidak dapat akses secara ekonomi, dengan adanya pembiayaan mereka dapat melakukan akses ekonomi.

b. Tersedianya dana bagi peningkatan usaha, artinya: untuk pengembangan usaha membutuhkan dana tambahan.

c. Meningkatkan produktivitas, artinya: adanya pembiayaan memberikan peluang bagi masyarakat usaha mampu meningkatkan daya produksinya.

d. Membuka lapangan kerja baru, artinya: dengan dibukanya sektor-sektor usaha melalui penambahan dana pembiayaan, maka sektor usaha tersebut akan menyerap tenaga kerja.

e. Terjadi distribusi pendapatan, artinya: masyarakat usaha produktif mampu melakukan aktivitas kerja, berarti mereka akan memperoleh pendapatan dari hasil usahanya.

Adapun secara mikro, pembiayaan diberikan dalam rangka untuk:

a. Upaya memaksimalkan laba, artinya: setiap usaha yang dibuka memiliki tujuan tertinggi, yaitu menghasilkan laba usaha.

b. Upaya meminimalkan risiko, artinya: usaha yang dilakukan agar mampu menghasilkan laba maksimal, maka pengusaha harus mampu meminimalkan risiko yang mungkin timbul.

c. Pendayagunaan sumber ekonomi, artinya sumber daya ekonomi dapat dikembangkan dengan melakukan mixing antara sumber daya alam dengan sumber daya manusia serta sumber daya modal.

d. Penyaluran kelebihan dana, artinya: dalam kehidupan masyarakat ini ada pihak yang memiliki kelebihan sementara ada pihak yang kekurangan.

\section{Fungsi Pembiayaan}

${ }^{8}$ Muhammad, Manajemen Pembiayaan Bank Syari'ah..., h. 41 
Pembiayaan secara umum memiliki fungsi untuk: (a) Meningkatkan daya guna uang, (b) Meningkatkan daya guna barang, (c) Meningkatkan peredaran uang, (d) Menimbulkan kegairahan usaha, (e) Stabilitas ekonomi, (f) Sebagai jembatan untuk meningkatkan pendapatan nasional. ${ }^{9}$

Pembiayaan yang diberikan oleh bank Syari'ah berfungsi membantu masyarakat daalam memenuhi kebutuhan dalam meningkatkan usahanya. Secara perinci pembiayaan memiliki fungsi antara lain: (a) Pembiayaan dapat meningkatkan arus tukar-menukar barang dan jasa, (b) Pembiayaan merupakan alat yang dipakai untuk memanfaatkan idle fund, (c) Pembiayaan sebagai alat pengendali harga, (d) Pembiayaan dapat mengaktifkan dan meningkatkan manfaat ekonomi yang ada. ${ }^{10}$

\section{E. Unsur-Unsur Pembiayaan}

a. Bank Syari'ah, merupakan badan usaha yang memberikan pembiayaan kepada pihak lain yang membutuhkan dana.

b. Mitra Usaha atau Partner, merupakan pihak yang mendapatkan pembiayaan dari bank Syari'ah, atau pengguna dana yang disalurkan oleh bank Syari'ah.

c. Keprcayaan (Trust), bank Syari'ah memberikan kepercayaan kepada pihak yang menerima pembiayaan bahwa mitra akan memenuhi kewajiban untuk mengembalikan dana bank Syari'ah sesuai dengan jangka waktu tertentu yang diperjanjikan.

d. Akad, akad merupakan suatu kontrak perjanjian atau kesepakatan yang dilakukan antara bank Syari'ah dan pihak nasabah atau mitra.

e. Risiko, merupakan kemungkinan kerugian yang akan timbul karena dana yang disalurkan tidak dapat kembali.

f. Jangka Waktu, merupakan periode waktu yang diperlukan oleh nasabah untuk membayar kembali pembiayaan yang telah diberikan oleh bank Syari'ah. Jangka waktu dapat bervariasi antara lain jangka pendek, jangka menengah, dan jangka panjang.

\footnotetext{
${ }^{9}$ Muhammad, Manajemen Pembiayaan Bank Syari'ah..., h. 43-45

${ }^{10}$ Ismail, Perbankan Syari'ah..., h. 108-109
} 
g. Balas Jasa, sebagai balas jasa atas dana yang disalurkan oleh bank Syari'ah, maka nasabah membayar jumlah tertentu sesuai dengan akad yang telah disepakati antara bank dan nasabah. ${ }^{11}$

\section{F. Jenis-jenis Pembiayaan}

\section{Pembiayaan Modal Kerja}

Secara umum, yang dimaksud dengan Pembiayaan Modal Kerja (PMK) Syari'ah adalah pembiayaan jangka pendek yang diberikan kepada perusahaan untuk membiayai kebutuhan modal kerja usahanya berdasarkan prinsip-prinsip Syari'ah. ${ }^{12}$ Jangka waktu pembiayaan modal kerja maksimum 1 (satu) tahun dan dapat di perpanjang sesuai dengan kebutuhan. Perpanjangan fasilitas PMK dilakukan atas dasar hasil analisis terhadap debitur dan fasilitas pembiayaan secara keseluruhan.

Berdasarkan akad yang digunakan dalam produk pembiayaan Syari'ah, jenis Pembiayaan Modal Kerja (PMK) dapat dibagi menjadi 5 macam, yakni:
(a) PMK Mudharabah,
(b) PMK Istishna,
(c) PMK Salam,
(d) PMK Murabahah, (e) PMK Ijarah.

\section{Pembiayaan Investasi}

Investasi adalah penanaman dana dengan maksud untuk memperoleh imbalan/manfaat/keuntungan di kemudian hari. Pembiayaan investasi adalah pembiayaan jangka menengah atau jangka panjang untuk pembelian barangbarang modal yang diperlukan. ${ }^{13}$ Pembiayaan investasi diberikan kepada para nasabah untuk keperluan investasi, yaitu keperluan penambahan modal guna mengadakan rehabilitasi, perluasan usaha, ataupun pendirian proyek baru.

Ciri-ciri pembiayaan investasi adalah: (1) Untuk pengadaan barangbarang modal; (2) Mempunyai perencanaan lokasi dana yang matang dan terarah; (3) Berjangka waktu menengah dan panjang. ${ }^{14}$

Melihat luasnya aspek yang harus dikelola dan dipantau maka untuk pembiayaan investasi bank Syari'ah menggunakan skema musyarakah

\footnotetext{
${ }^{11}$ Ismail, Perbankan Syari'ah..., h. 107-108

12 Adiwarman A. Karim, Bank Islam: Analisis Fiqih dan Keuangan..., h. 234

${ }^{13}$ Adiwarman A. Karim, Bank Islam: Analisis Fiqih..., h. 236-237

${ }^{14}$ Muhammad Syafi'i Antonio, Bank Syari'ah: Teori kePraktik..., h. 167
} 
mutanaqishah. Dalam hal ini bank memberikan pembiayaan dengan prinsip penyertaan, dan secara bertahap bank melepaskan penyertaannya dan pemilik perusahaan akan mengambil alih kembali, baik dengan menggunakan surplus cash flow yang tercipta maupun dengan menambah modal, baik yang berasal dari setoran pemegang saham yang ada maupun dengan mengundang pemegang saham baru.

\section{Pembiayaan Konsumtif}

Secara definitif, konsumsi adalah kebutuhan individual meliputi kebutuhan baik barang maupun jasa yang tidak dipergunakan untuk tujuan usaha. Dengan demikian, yang dimaksud dengan pembiayaan konsumtif adalah jenis pembiayaan yang diberikan untuk tujuan diluar usaha dan umumnya bersifat perorangan. ${ }^{15}$ Pembiayaan Konsumtif, yaitu pembiayaan yang digunakan untuk memenuhi kebutuhan konsumsi, yang akan habis digunakan untuk memenuhi kebutuhan. ${ }^{16}$

Menurut jenis akadnya dalam produk pembiayaan Syari'ah, pembiayaan konsumtif dapat dibagi menjadi lima bagian, yaitu: (1) Pembiayaan konsumen akad Murabahah, (2) Pembiayaan konsumen akad IMBT, (3) Pembiayaan konsumen akad Ijarah, (4) Pembiayaan konsumen akad Istishna, (5) Pembiayaan konsumen akad Qard + Ijarah.

Bank Syari'ah dapat menyediakan pembiayaan komersil untuk pemenuhan kebutuhan barang konsumsi dengan menggunakan skema: (1) Albai bi tsaman ajil (salah satu bentuk murabahah) atau jual beli dengan angsuran. (2) Al-ijarah al-muntahia bit-tamlik atau sewa beli. (3) Almusyarakah mutanaqishah atau descreasing participation, di mana secara bertahap bank menurunkan jumlah partisipasinya. (4) Ar-rahn untuk memenuhi kebutuhan jasa.

Pembiayaan konsumsi tersebut di atas lazim digunakan untuk pemenuhan kebutuhan sekunder. Adapun kebutuhan primer pada umumnya tidak dapat dipenuhi dengan pembiayaan komersil. Seseorang yang belum mampu

\footnotetext{
15 Adiwarman A. Karim, Bank Islam: Analisis Fiqih dan Keuangan..., h. 244

${ }^{16}$ Muhammad Syafi'i Antonio, Bank Syari'ah..., h. 160
} 
memenuhi kebutuhan pokonya tergolong fakir atau miskin. Oleh karena itu, ia wajib diberi zakat atau sedekah, atau maksimal diberikan pinjaman kebajikan (al-qardh al-hasan), yaitu pinjaman dengan kewajiban pengembalian pinjaman pokok saja, tanpa imbalan apa pun. ${ }^{17}$

\section{Prinsip-Prinsip Pembiayaan}

Dalam pemberian pembiayaan terdapat prinsip-prinsip yaitu prinsip $5 \mathrm{C}+1 \mathrm{~S}$ sebagai berikut:

a. Character

Menggambarkan watak dan kepribadian calon nasabah. Bank perlu melakukan analisis terhadap karakter calon nasabah dengan tujuan untuk mengetahui bahwa calon nasabah mempunyai keinginan untuk memenuhi kewajiban membayar kembali pembiayaan yang telah diterima hingga lunas.

b. Capacity

Analisis terhadap capacity ini ditujukan untuk mengetahui kemampuan keuangan calon nasabah dalam memenuhi kewajibannya sesuai jangka waktu pembiayaan.

c. Capital

Capital atau modal yang perlu disertakan dalam objek pembiayaan perlu dilakukan analisis yang lebih mendalam. Modal merupakan jumlah modal yang dimiliki oleh calon nasabah atau jumlah dana yang akan disertakan dalam proyek yang dibiayai.

d. Collateral

Merupakan agunan yang diberikan calon nasabah atas pembiayaan yang diajukan. Agunan merupakan sumber pembayaran kedua. Dalam analisis agunan, faktor yang sangat penting dan harus diperhatikan adalah purnajual dari agunan yang diserahkan kepada bank. Bank Syari'ah perlu mengetahui minat pasar terhadap agunan yang diserahkan oleh calon nasabah. Bila agunan merupakan barang yang diminati oleh banyak orang (marketable), maka bank yakin bahwa agunan yang diserahkan calon nasabah mudah diperjualbelikan.

\footnotetext{
${ }^{17}$ Muhammad Syafi'i Antonio, Bank Syari'ah: Teori kePraktik..., h. 168
} 


\section{e. Condition of Economi}

Merupakan analisis terhadap kondisi perekonomian. Bank perlu melakukan analisis dampak kondisi ekonomi terhadap usaha calon nasabah di masa yang akan datang, untuk mengetahui pengaruh kondisi ekonomi terhadap usaha calon nasabah. ${ }^{18}$

f. Syari'ah

Prinsip Syari'ah menurut UU NO. 21 Tahun 2008, adalah prinsip hukum Islam dalam kegiatan perbankan berdasarkan fatwa yang dikeluarkan oleh lembaga yang memiliki kewenangan dalam penetapan fatwa di bidang Syari'ah. ${ }^{19}$ Syari'ah merupakan ketentuan hukum islam yang mengatur aktivitas umat manusia yang berisi perintah dan larangan, baik yang menyangkut hubungan interaksi vertical dengan Tuhan maupun interaksi horisontal sesama makhluk. ${ }^{20}$ Prinsip Syari'ah yang berlaku umum dalam kegiatan muamalah (transaksi Syari'ah) mengikat secara hukum bagi semua pelaku dan stakeholder entitas yang melakukan transaksi Syari'ah.

\section{Pengertian Musyarakah}

Istilah lain dari Musyarakah adalah syarikah atau syirkah. ${ }^{21}$ Musyarakah atau syirkah dari segi bahasa berarti percampuran. ${ }^{22}$ Musyarakah yaitu akad kerja sama antara dua pihak atau lebih untuk suatu usaha tertentu, dimana masing-masing pihak memberikan kontribusi dana (atau amal/ expertise) dengan kesepakatan bahwa keuntungan dan risiko akan ditanggung bersama sesuai dengan kesepakatan. ${ }^{23}$ Musyarakah merupakan aktivitas berserikat dalam melaksanakan usaha bersama antara pihak-pihak yang terkait. Dalam syirkah, dua orang atau lebih mitra menyumbang untuk memberikan modal guna menjalankan usaha atau melakukan investasi untuk suatu usaha. Hasil

\footnotetext{
${ }^{18}$ Ismail, Perbankan Syari'ah..., h. 120-126

${ }^{19}$ Muhammad Saleh \& Ikit, Pengantar Bank Syari'ah..., h. 68

${ }^{20}$ Ikit, Akuntansi Penghimpunan Dana Bank Syari'ah..., h. 141

${ }^{21}$ Heri Sudarsono, Bank dan Lembaga Keuangan Syari'ah, (Yogyakarta: Ekonosia, 2003), h. 67

${ }^{22}$ Muhammad, Teknik dan Perhitungan Bagi Hasil dan Profit Margin pada Bank Syari'ah, (Yogyakarta: UII Press, 2004) h. 79

${ }^{23}$ Amir Machmud \& Rukmana, Bank Syari'ah: Teori,Kebijakan, dan Studi Empiris di Indonesia, (Jakarta: PT. Gelora Aksara Pratama, 2010), h. 27
} 
usaha atas mitra usaha dalam syirkah akan dibagi sesuai dengan nisbah yang telah disepakati oleh pihak-pihak yang berserikat. ${ }^{24}$

Secara sederhana Musyarakah dapat diartikan akad kerjasama usaha patungan antara 2 (dua) pihak atau lebih pemilik modal untuk membiayai suatu jenis usaha yang halal dan produktif. Pendapatan atau keuntungan dibagi sesuai dengan nisbah yang telah di sepakati bersama pada saat melakukan akad. Bank disini melakukan usaha pembiayaan dengan cara menyertakan modal kedalam suatu perusahaan yang menerima pembiayaannya. Bank bersama mitra usaha mengadakan kesepakatan tentang pembagian keuntungan dari usaha yang dibiayai. Porsi pembagian keuntungan tidak harus sebanding dengan pangsa pembiayaan masing-masing, tetapi atas dasar perjanjian kedua belah pihak. Apabila terjadi kerugian, maka kerugian tersebut akan ditanggung bersama sesuai dengan pangsa pembiayaan masing-masing. Dalam hal ini Bank dapat ikut serta mengelola usaha tersebut. ${ }^{25}$ Transaksi musyarakah dilandasi adanya keinginan para pihak yang bekerja sama untuk meningkatkan nilai aset yang mereka miliki secara bersama-sama. Semua bentuk usaha yang melibatkan dua pihak atau lebih dimana mereka secara bersama-sama memadukan seluruh bentuk sumber daya baik yang berwujud maupun tidak berwujud. ${ }^{26}$

Musyarakah pada umumnya merupakan perjanjian yang berjalan terus sepanjang usaha yang di biayai bersama terus beroperasi. Meskipun demikian, perjanjian musyarakah dapat di akahiri dengan atau tanpa menutup usaha. Apabila usaha di tutup dan di likuidasi, maka masing-masing mitra usaha mendapat hasil likuidasi aset sesuai nisbah penyertaannya. Apabila usaha terus berjalan, maka mitra usaha yang ingin mengakhiri perjanjian dapat menjual sahamnya ke mitra usaha yang lain dengan harga yang disepakati bersama. ${ }^{27}$ Dikemukakan pula dengan adanya akad syirkah yang disepakati kedua belah

\footnotetext{
${ }^{24}$ Ismail, Perbankan Syari'ah..., h. 176

${ }^{25}$ Rachmadi Usman, Aspek-Aspek Hukum Perbankan Islam di Indonesia, (Bandung: PT Citra Aditya Bakti, 2002), h. 19

${ }^{26}$ Adiwarman A. Karim, Bank Islam: Analisis Fiqih dan Keuangan..., h. 102

${ }^{27}$ Ascarya, Akad \& Produk Bank Syari'ah, Cet. 4, (Jakarta: Rajawali Pers, 2013), h. 52
} 
pihak, maka semua pihak yang mengikat diri berhak bertindak hukum terhadap harta syarikat itu dan berhak mendapatkan keuntungan sesuai yang disepakati. ${ }^{28}$

\section{Landasan Syari’ah Musyarakah}

a. Al-Quran

Artinya: “...tetapi jika saudara-saudara seibu itu lebih dari seorang,

Maka mereka bersekutu dalam yang sepertiga itu..." (An-Nisaa': 12)

Artinya: “...dan Sesungguhnya kebanyakan dari orang-orang yang berserikat itu sebahagian mereka berbuat zalim kepada sebahagian yang lain, kecuali orang-orang yang beriman dan mengerjakan amal yang saleh; dan Amat sedikitlah mereka ini..." (Shaad: 24)

b. Al-Hadits

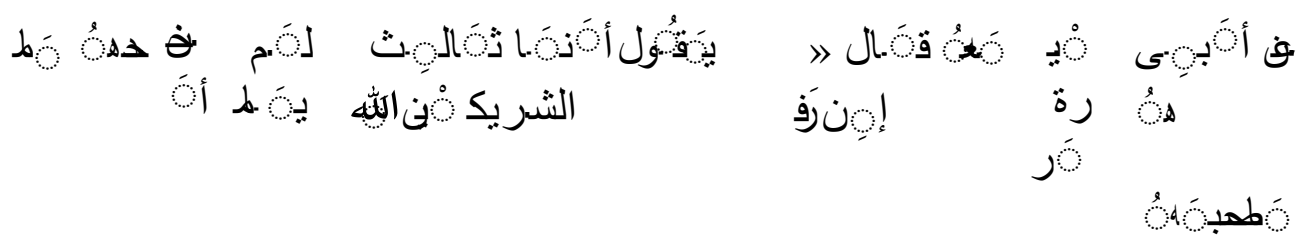

Artinya: Dari Abu Hurairah, Rasulullah saw. bersabda, "Sesungguhnya Allah Azza wa Jalla berfirman: 'Aku pihak ketiga dari dua orang yang berserikat selama salah satunya tidak menghianati lainnya'." (HR. Abu Dawud no. 2936, dalam kitab al-Bayu, dan Hakim).

c. Ijma'

Ibnu Qudamah dalam kitabnya, al-Mughni, telah berkata, "Kaum muslimin telah berkonsensus terhadap legitimasi musyarakah secara

${ }^{28}$ Nasrun Haroen, Fiqh Muamalah, (Jakarta : Gaya Media Pratama, 2007), h. 166 
global walaupun terdapat perbedaan pendapat dalam beberapa elemen daripadanya". ${ }^{29}$

\section{Jenis-Jenis Musyarakah}

Menurut syariat Islam, syirkah atau musyarakah dibagi menjadi dua jenis yaitu syirkah al-Milk (musyarakah pemilikan) dan syirkah al-Uqud (musyarakah akad/ kontrak). Syirkah al-Milk adalah kepemilikan lebih dari satu orang terhadap suatu barang tanpa diperoleh melalui akad. ${ }^{30}$ Musyarakah pemilikan tercipta karena warisan, wasiat, atau kondisi lainnya yang mengakibatkan pemilikan satu aset oleh dua orang atau lebih. Dalam musyarakah ini, kepemilikan dua orang atau lebih berbagi dalam suatu aset nyata dan berbagi pula dalam keuntungan yang dihasilkan aset tersebut.

Syirkah al-Uqud atau akad adalah kemitraan yang terjadi karena adanya kontrak bersama, atau usaha komersial bersama. ${ }^{31}$ Musyarakah akad ini tercipta dengan cara kesepakatan di mana dua orang atau lebih setuju bahwa tiap orang dari mereka memberikan modal musyarakah. Mereka pun sepakat berbagi keuntungan dan kerugian.

Syirkah al-Uqud dibagi menjadi lima jenis:

a. Syirkah Mufawwadhah merupakan akad kerja sama usaha antara dua pihak atau lebih, yang masing-masing pihak harus menyerahkan modal dengan porsi modal yang sama dan bagi hasil atas usaha atau risiko ditanggung bersama dengan jumlah yang sama. Dalam syirkah mufawwadhah, masingmasing mitra usaha memiliki hak dan tanggung jawab yang sama.

b. Syirkah Inan merupakan akad kerja sama usaha antara dua orang atau lebih, yang masing-masing mitra kerja harus menyerahkan dana untuk modal yang porsi modalnya tidak harus sama. Pembagian hasil usaha sesuai dengan kesepakatan, tidak harus sesuai dengan kontribusi dana yang diberikan. Dalam syirkah inan, masing-masing pihak tidak harus menyerahkan modal

\footnotetext{
${ }^{29}$ Karnaen Perwataatmadja dan Muhammad Syafi'i Antonio, Apa dan Bagaimana Bank Islam, Cet. 3, (Yogyakarta: PT. Dana Bhakti Prima Yasa, 1999), h. 23-24

${ }^{30}$ Muhammad Saleh \& Ikit, Pengantar Bank Syari'ah..., h. 98

${ }^{31}$ Ascarya, Akad \& Produk Bank Syari'ah..., h. 49-50
} 
dalam bentuk uang tunai saja, akan tetapi dapat dalam bentuk aset atau kombinasi antara uang tunai dan aset atau tenaga. ${ }^{32}$

c. Syirkah A'maal atau disebut juga dengan syirkah 'abdan merupakan kerja sama antara satu dengan pihak lain atau lebih dalam bentuk kerja (tanpa memberikan modal) untuk menerima pekerjaan secara bersama dan berbagi keuntungan dari pekerjaan itu. Atau dua orang sepakat untuk menerima suatu pekerjaan dengan ketentuan upah dibagi menurut kesepakatan.

d. Syirkah Wujuh adalah akad kerja sama antara satu pihak dengan pihak lain yang membeli sesuatu tanpa memiliki modal, hanya berpegang kepada nama baik (reputasi) dan kepercayaan pedagang. Dengan catatan bahwa keuntungan untuk mereka berdua sesuai dengan akad. Syirkah wujuh ini merupakan syirkah tanggung jawab tanpa modal karena pembelian barang berdasarkan pada nama baik seseorang. ${ }^{33}$

e. Syirkah Mudharabah merupakan kerja sama usaha antara dua pihak atau lebih yang mana satu pihak sebagai shahibul maal yang menyediakan dana $100 \%$ untuk keperluan usaha, dan pihak lain tidak menyerahkan modal dan hanya sebagai pengelola atas usaha yang dijalankan, disebut mudharib. ${ }^{34}$

\section{Penutup}

Pembiayaan musyarakah adalah akad kerjasama antara dua pihak untuk membiayai usaha tertentu, dimana kedua belah pihak sama-sama menyertakan modal yang masing-masing disebut dengan syirkah. Ketentuan modal tergantung kesepakatan kedua belah pihak dan bagi hasil sesuai dengan porsi modal masing-masing. Pembiayaan akad musyarakah pada Bank Sumsel Babel Cabang Pembantu Syari'ah Muara Kelingi berkembang cukup pesat. Proses atau prosedur pembiayaan musyarakah melalui beberapa tahapan yaitu pengajuan permohonan dan persyaratan pembiayaan dari nasabah kepada Bank Sumsel Babel Cabang Pembantu Syari'ah Muara Kelingi. Kemudian pemeriksaan berkas dan dokumen yang diperlukan oleh Bank, untuk

\footnotetext{
${ }^{32}$ Ismail, Perbankan Syari'ah..., h. 177-178

${ }^{33}$ Muhammad Saleh \& Ikit, Pengantar Bank Syari'ah..., h. 99

${ }^{34}$ Ismail, Perbankan Syari'ah..., h. 179
} 
mengetahui apakah berkas atau dokumen yang diajukan sudah benar, lengkap dan sesuai dengan persyaratan telah yang ditetapkan. Selanjutnya peninjauan ke lokasi (survey) untuk mengetahui kebenaran tentang data yang diberikan calon nasabah kepada Bank.

Faktor pendukung pelaksanaan pembiayaan musyarakah pada Bank Sumsel Babel Cabang Pembantu Syari'ah Muara Kelingi adalah Modal adalah dana yang digunakan untuk pembiayaan musyarakah merupakan dana yang bersumber dari dana APBD, Tingkat promosi yang baik, adalah Bank melakukan promosi dengan mengadakan gathering kepada para kontraktor khususnya para kontraktor daerah Musi Rawas dan Lubuk Linggau. Proyek, adalah banyaknya pembangunan dan perbaikan infrastruktur transportasi khususnya di daerah musi Rawas dan Lubuk Linnggau. Selain faktor pendukung.

\section{Daftar Pustaka}

Adiwarman A. Karim, Bank Islam: Analisis Fiqih dan Keuangan, Cet.11, Jakarta: PT. Raja Grafindo Persada, 2016

Afifah Tri Sukmawati, Skripsi, Sistem Pembiayaan dan Perhitungan Bagi Hasil Produk Musyarakah di BMT Al-Ikhlas, Jurusan Manajemen Dakwah, Fakultas Dakwah dan Komunikasi, Universitas Islam Negeri Sunan Kalijaga, Yogyakarta, 2014

Ahmad Ifham Sholihin, Pedoman Umum Lembaga Keuangan Syari'ah, Jakarta: PT Gramedia Puataka Utama, 2010

Amir Machmud \& Rukmana, Bank Syari'ah: Teori,Kebijakan, dan Studi Empiris di Indonesia, Jakarta: PT. Gelora Aksara Pratama, 2010

Ascarya, Akad \& Produk Bank Syari'ah, Cet. 4, Jakarta: Rajawali Pers, 2013

Destri Budi Nugraheni, Jurnal Mimbar Hukum, Asas Kesetaraan dalam Akad Pembiayaan Musyarakah pada Bank Syari'ah di Yogyakarta, Fakultas Hukum UGM, 2012

Ismail, Perbankan Syari'ah, Cet. 1, Jakarta: Kencana, 2011 
Karnaen Perwataatmadja dan Muhammad Syafi'i Antonio, Apa dan Bagaimana Bank Islam, Cet. 3, Yogyakarta: PT. Dana Bhakti Prima Yasa, 1999

M. Nur Rianto Al Arif, Pengantar Ekonomi Syari'ah: Teori dan Praktik, Cet.1, Bandung: CV Pustaka Setia, 2015

Muhammad Saleh \& Ikit, Pengantar Bank Syari'ah, Cet.1, Lubuklinggau: Pustaka Al-Azhaar, 2014

Muhammad Syafi'i Antonio, Bank Syari'ah: Dari Teori ke Praktik, Cet. 1, Jakarta: Gema Insani, 2001

Muhammad, Manajemen Pembiayaan Bank Syari'ah, Cet.1, Yogyakarta: UPP STIM YKPN, 2016

Nasrun Haroen, Fiqh Muamalah, Jakarta : Gaya Media Pratama, 2007

Rachmadi Usman, Aspek-Aspek Hukum Perbankan Islam di Indonesia, Bandung: PT Citra Aditya Bakti, 2002

Sugiyono, Metode Penelitian Pendidikan: Pendekatan Kuantitatif, Kualitatif, dan $R \& D$, Bandung: ALFABETA, 2015

Veitzal Rivai, Islamic Banking, Jakarta: PT Bumi Aksara, 2010 